\title{
Status of Charcoal Canker on Oak Trees at a Site of Community Importance: Case Study of the Relict Castelfidardo Forest (SIC Area IT520008, Castelfidardo, AN, Italy)
}

\author{
Sergio Murolo ${ }^{1, *} \mathbb{( D}$, Jonathan Concas ${ }^{1}$, Alessandro Salerno ${ }^{1}$, Fedele Maiorano ${ }^{1}$, Lorenzo Cingolani ${ }^{1}$, \\ Francesca Carloni ${ }^{1}$, Salvatore Moricca ${ }^{2}$ a) and Gianfranco Romanazzi ${ }^{1}$ (i) \\ 1 Department of Agricultural, Food and Environmental Science, Marche Polytechnic University, \\ 60131 Ancona, Italy; john.concas@gmail.com (J.C.); alex.sale@hotmail.it (A.S.); fefemaio@live.it (F.M.); \\ lory.cingo@hotmail.com (L.C.); francesca.carloni96@gmail.com (F.C.); g.romanazzi@univpm.it (G.R.) \\ 2 Department of Agricultural, Food, Environmental and Forest Sciences and Technologies, University of \\ Florence, 50144 Florence, Italy; salvatore.moricca@unifi.it \\ * Correspondence: s.murolo@univpm.it; Tel.: +39-071-2204697; Fax: +39-071-2204856
}

Citation: Murolo, S.; Concas, J.; Salerno, A.; Maiorano, F.; Cingolani, L.; Carloni, F.; Moricca, S.; Romanazzi, G. Status of Charcoal Canker on Oak Trees at a Site of Community Importance: Case Study of the Relict Castelfidardo Forest (SIC Area IT520008, Castelfidardo, AN, Italy). Forests 2021, 12, 1032. https:// doi.org/10.3390/f12081032

Academic Editor: Benedetto T. Linaldeddu

Received: 28 June 2021

Accepted: 30 July 2021

Published: 4 August 2021

Publisher's Note: MDPI stays neutral with regard to jurisdictional claims in published maps and institutional affiliations.

Copyright: (c) 2021 by the authors. Licensee MDPI, Basel, Switzerland. This article is an open access article distributed under the terms and conditions of the Creative Commons Attribution (CC BY) license (https:// creativecommons.org/licenses/by/ $4.0 /)$.

\begin{abstract}
Oaks are dominant and key tree species in Mediterranean forest ecosystems. However, in recent decades, oak forests have been heavily impacted by oak decline, a worldwide phenomenon exacerbated by climate change. The charcoal disease agent Biscogniauxia mediterranea is involved in the decline of Mediterranean oak formations in a variety of contexts. Here, we investigated the impact and role of B. mediterranea in the decline of oaks in Castelfidardo Forest, a relict wood of the late Holocene and a Site of Community Importance. We established five plots within which we recorded tree positions, any symptoms and signs of decline, association of B. mediterranea to declining trees, and deadwood and associated mycota. Of 471 oaks inspected, $7.0 \%$ showed brownish exudates on the stems, $46.9 \%$ showed epicormic shoots along the main trunk, and $24.4 \%$ showed black carbonaceous stromata on diseased branches and trunks. The decline was most severe for Quercus cerris, which comprised plots \#4 and \#5, at 50.0\% (81/162 trees) and 29.0\% (33/114), respectively; then for Quercus robur for plot \#3, at 40.0\% (38/95); and finally for Quercus pubescens for plots \#1 and \#2, at 13.7\% (7/51) and $12.3 \%(6 / 49)$, respectively. Bark tissues were collected from trees with charcoal cankers and taken to the laboratory for microscopic examination and identification by mycological and molecular methods. This investigation revealed a close association between oaks with pronounced reduction of vitality and incidence of $B$. mediterranea. Deadwood was equally distributed among the five plots, and was heavily colonized by Basidiomycota. The high incidence of the charcoal canker pathogen $B$. mediterranea appeared to be related to environmental stresses. However, the absence of silvicultural management, high competition among physiologically mature trees, and the geographic isolation of this residual forest may have predisposed oaks to decline.
\end{abstract}

Keywords: Biscogniauxia mediterranea; oak decline; dieback; Site of Community Importance (S.I.C.); tree competition; warming conditions

\section{Introduction}

Forest decline may be considered the most worrying and complex syndrome that affects wide forested areas across a range of ecosystems throughout the world [1-5]. When dealing with forest decline in the Mediterranean area, special attention should be focused on oak forests, due to the importance and widespread presence of oaks in Mediterranean forest ecosystems and the severity and extent of the decline in oak formations [6].

Oak decline involves various members of the genus Quercus, and it is seen as a general and progressive decline that is accompanied by a range of symptoms. The most common of these are: leaf chlorosis and yellowing; microphyllia; premature leaf drop and crown transparency; branch dieback; emission of dark exudates through the trunk; and production 
of epicormic shoots along the main branches and stems [7,8]. Indeed, oak decline has long been recognized as a complex, multifactorial disease that involves a variety of predisposing factors, inciting factors, and contributing factors [1,9].

The most common predisposing factors are those that reduce the natural host defenses, which can induce chronic metabolic disorders that debilitate trees and make them more prone to long-term effects of damaging agents. These include factors related to climate, site, and anthropogenic interference, such as water stress from extended drought, poor soil conditions, waterlogging, silvicultural mismanagement and land-use disturbance. Inciting factors can be physical or biological, and they can act episodically and over short durations, such as hail, frost, acute water shortage, and defoliating insects. These factors induce acute, short-term damage, so these symptoms of the decline can regress, and the plants can recover. However, if the damage is prolonged and repeated over several years, this can irreversibly weaken the trees, and potentially cause their death. Contributing factors are those factors that further debilitate trees, and when these act on physiologically impaired trees, they can become lethal. Among these, there are secondary biotic agents, such as weakening pathogens, boring insects, and bark beetles [1,10-15].

All of these damaging factors can be implicated singly or cumulatively in the decline of oaks, with the variously focused actions showing different levels of intensity and, as a consequence, resulting in varying damage severity. Cumulative or alternative involvement of these stressors can give rise to a number of syndromes that are variable from site to site. This has resulted in the generation of diverse and sometimes conflicting hypotheses on the etiology of these phenomena, which has resulted in the definition of oak decline as a "complex of different diseases" [1,10].

In recent years, changes in temperature and rainfall patterns have begun to have increasingly important and decisive roles in oak decline [16-19]. The climate of the Mediterranean basin has shown a general tendency to become warmer and drier [20,21]. Here, the persistent stressful conditions caused by prolonged water deficit and drought stress can weaken the trees and make them more vulnerable to infection by secondary, opportunistic pathogens [22,23].

Members of the genus Quercus are widespread on the Italian peninsula, and thus they characterize its national and local landscape [24,25]. Castelfidardo Forest (Selva di Castelfidardo) is an example of a forest with high landscaping and ecological value in which Quercus spp. are the dominant tree component. This forest is recognized as a 'Site of Community Importance, and has been included in the European "Natura 2000" network, an international system of protected areas that is designed to safeguard European habitats and biodiversity. As Castelfidardo Forest is a protected area of natural heritage, and as many oaks within this forest have recently shown increasing symptoms of decline and mortality, we investigated the causes of this general, progressive decline and dieback.

Castelfidardo Forest is a sub-Mediterranean deciduous forest with mesophilic traits that today covers an area of only 36 ha, although at the beginning of the seventeenth century it was known to have extended to the sea, with an estimated area of $\sim 350$ hectares. The original area has therefore undergone significant contraction over time, to the point that Castelfidardo Forest can be considered today as a lowland residual forest within a widely cultivated hilly landscape [26].

A temperate bioclimate is predominant in this area, with rainfall patterns that provide between $300 \mathrm{~mm}$ and $600 \mathrm{~mm}$ per year of rainfall that is mainly concentrated over the autumn and winter months, resulting in prolonged, dry summers. The northern exposure, the geological characteristics of the site, and the relatively humid soil due to the superficial aquifer (especially in the lower portion of the forest) have created a microclimate that differs from the surrounding hills and from the coastal areas, such that the vegetation expresses sub-Mediterranean phytoclimatic conditions [27].

The composition of Castelfidardo Forest has been shaped by the nature of the geological substrate, the morphological structure of the area, and anthropogenic interference. Its core areas mainly include deciduous Quercus species (i.e., Quercus cerris, Quercus robur, 
Quercus pubescens), whereas parts of the edges of the forest have been reforested with Pinus spp. and Cupressus spp. (Ministerial Decree, 30 March 2009) (Figure 1). However, Castelfidardo Forest has been undergoing diffuse deterioration, with loss of biodiversity and general decline. This is due to the monoplane structure of Castelfidardo Forest, which has a dominant layer of roughly even-aged trees, and lack of silvicultural management, high stand density, strong competition among individuals, and the pedoclimatic characteristics of the area. Furthermore, it represents a small, isolated remnant of a late Holocene forest that has long been isolated from continuous forests.

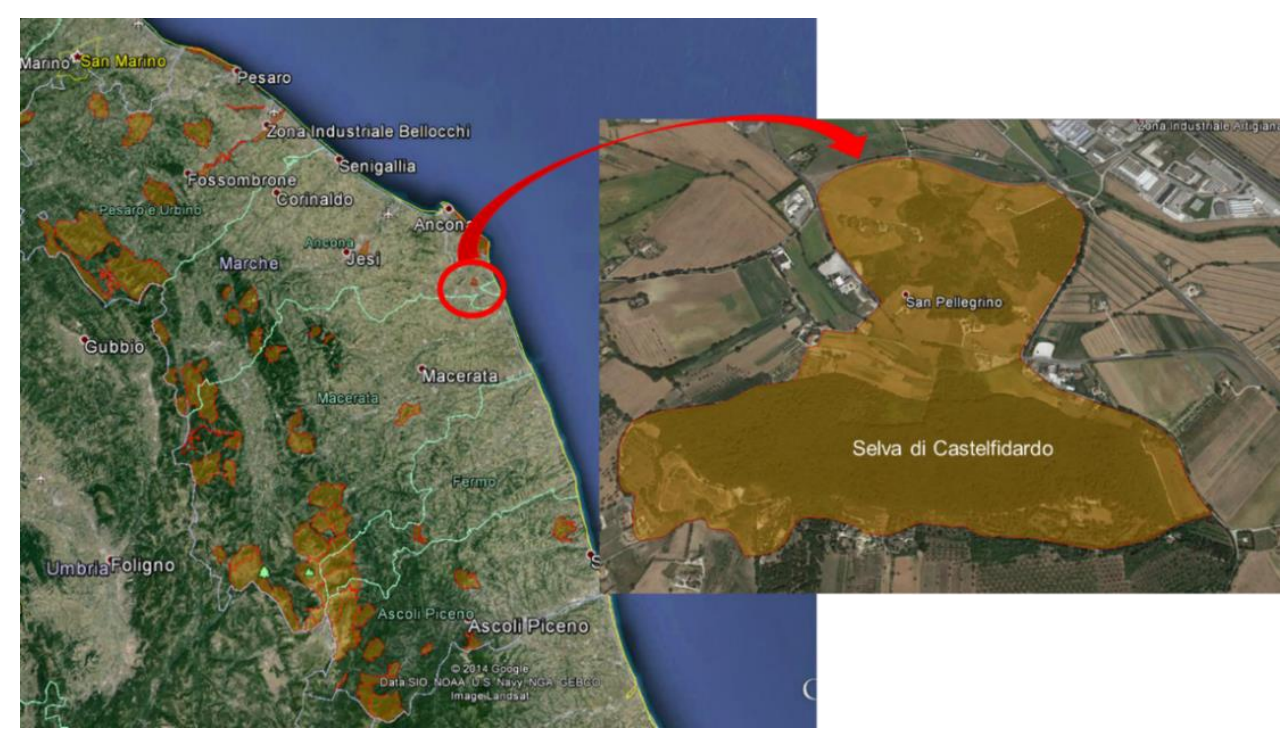

Figure 1. Map of Castelfidardo Forest (Selva di Castelfidardo; Site of Community Importance; Castelfidardo, AN, Italy) instituted by Ministerial Decree 30 March 2009.

The aims of this study were to: (i) determine the health conditions of the oak trees in the Castelfidardo Forest; (ii) describe the incidence of the charcoal canker pathogen Biscogniauxia mediterranea on the declining oaks; (iii) determine the amounts of deadwood and take a census of the associated Mycota; and (iv) determine whether there is a causeeffect relationship between climatic conditions and the decline of the oak species.

\section{Materials and Methods}

\subsection{Study Site, Plot Design, and Tree Health Assessment}

An examination of the phytosanitary status of the oak trees was carried out in the Castelfidardo Forest $\left(43^{\circ} 27^{\prime} 59^{\prime \prime} \mathrm{N}, 13^{\circ} 35^{\prime} 30^{\prime \prime} \mathrm{E}\right)$ from May to July 2015. For this purpose, five plots were located in the upper, middle, and lower areas that were representative of the soil types and vegetation that characterize the forest (Table 1). Each plot was circular, with an area ranging from 0.6 ha to 0.9 ha. The plots were of variable sizes and were designed to include all of the heterogeneity conditions in terms of soil type, vegetation, and intensity of decline.

Table 1. Main characteristics of plots studied in Castelfidardo Forest (Castelfidardo, AN, Italy).

\begin{tabular}{ccccc}
\hline Plots & Area $\mathbf{( m}^{\mathbf{2})}$ & Tree Species & $\begin{array}{c}\text { Stand Density } \\
\left(\text { Trees/100 } \mathbf{~ m}^{\mathbf{2}}\right)\end{array}$ & Trees Monitored (n) \\
\hline$\# \mathbf{1}$ & 6480.4 & Quercus pubescens + Fraxinus ornus & 11 & 51 \\
$\# \mathbf{2}$ & 8569.6 & Quercus pubescens + Fraxinus ornus & 9 & 49 \\
$\# \mathbf{3}$ & 6870 & Quercus robur + Carpinus betulus & 17 & 95 \\
$\# \mathbf{\# 5}$ & 7700 & Quercus cerris + Carpinus orientalis & 15 & 162 \\
\hline
\end{tabular}


In the upper layer, plots \#1 and \#2 were characterized by the arenaceous substrate where $Q$. pubescens was predominant, and was associated with sporadic presence of Fraxinus ornus trees. In plot \#3, in the middle layer, the dominant species was $Q$. robur, with rare Carpinus betulus found. In the lower layer, where plots \#4 and \#5 were located, the arenaceous component definitively disappeared, and the dominant forest vegetation was $Q$. cerris, with Carpinus orientalis occurring sporadically. In all of these plots, Ruscus aculeatus was the predominant understory species, and this covered large proportions of the plots, strongly limiting the natural regeneration of the oaks.

As summarized in Table 1, the main parameters recorded in each plot were: surface area; tree species; tree densities; and total numbers of trees inspected. A number of trees were selected according to the expression of symptoms (i.e., production of tarry exudates, epicormic shoot formation, and eruption of charcoal cankers through the bark), from 49 to 162 trees in each plot. For each tree selected, the diameter at chest height (i.e., $1.3 \mathrm{~m}$ above the ground) and its sanitary status were assessed and recorded, noting in particular the presence and frequency of: early symptoms of decline (e.g., emission of exudates, production of epicormic branches); advanced symptoms and/or signs of decline (e.g., dieback, black carbonaceous stromata indicative of charcoal cankers); and tree mortality. The position of each tree was recorded using the Global Positioning System (GPS; e-Trex 30, Garmin), and metallic labels with progressive identification numbers were affixed to the trunks. The data obtained relating to individual trees were managed through the Quantum Geographic Information System (GIS) open source software, and displayed using the Google Earth software.

The occurrence of saprotrophic and facultative necrotrophic fungi (e.g., Armillaria spp.; able to decompose deadwood) was also determined. Fruit bodies of these fungi were photographed, collected, and later identified through conventional morphological keys [28-30].

\subsection{Sample Collection, Mycological Analysis, and Morphological Identification}

Bark tissue with charcoal canker (mean dimension, $4 \times 4 \mathrm{~cm}$ ) was collected from $20 Q$. pubescens trees in plots \#1 and \#2, from 10 Q. robur trees in plot \#3, and from 20 Q. cerris trees in plots \#4 and \#5. These samples were incubated in a humidity chamber with five layers of tissue paper that had previously been soaked in sterile distilled water, and placed in glass Petri dishes (diameter, $14 \mathrm{~cm}$ ), at $25^{\circ} \mathrm{C}$, in the dark, for 10 days. The samples were then observed under a stereo microscope (MZ125; Leica) to document the sporulation. Various samples were photographed using a digital camera (FinePix S1 Pro; Fujifilm).

The fungal agents were isolated from the bark after the incubation in the humidity chamber, from differentiated fruiting structures. Under aseptic conditions, portions of the mycelia were transferred onto Petri dishes with potato dextrose agar (PDA) with added antibiotics (150 mg/L streptomycin, $150 \mathrm{mg} / \mathrm{L}$ ampicillin; to prevent bacterial contamination). Five original mycelial samples were put into each plate, and five replicates were prepared from each sample. Each plate was labeled, sealed with parafilm, and incubated at $25^{\circ} \mathrm{C}$ in the dark. After 5 days, the developed fungal colonies were subcultured onto fresh PDA plates, then transferred into glass test tubes, and finally stored at $4{ }^{\circ} \mathrm{C}$. For 50 isolates (10 for each plot), identification was carried out by recording the characteristics of 50-100 units of spores for each isolate, by light microscopy (Eclipse E600; Nikon).

\subsection{Molecular Identification of Fungal Colonies}

Mycelia were collected from 25 representative fungal colonies grown on PDA, transferred into $1.5 \mathrm{~mL}$ microcentrifuge tubes and pulverized, with the addition of $600 \mu \mathrm{L}$ extraction buffer (20 mM EDTA, 0.1 M Tris- $\mathrm{HCl}$, pH 8.0, 1.4 M NaCl, 2\% cetyltrimethylammonium bromide, $4 \%$ polyvinylpyrrolidone, $0.1 \%$ sodium metabisulfite [added just before use]). The extraction of total DNA was carried out using the CTAB protocol [31]. The quality and quantity of the extracted DNA were determined directly on 1\% agarose gels, with evaluation using a biophotometer (Eppendorf, Hamburg, Germany). The DNA was 
finally diluted to $10 \mathrm{ng} / \mu \mathrm{L}$ for further amplification. Nucleic acids were stored at $-20^{\circ} \mathrm{C}$, and later analyzed by polymerase chain reaction (PCR). Amplification of the $5.8 \mathrm{~S}$ ribosomal DNA (rDNA) and flanking internal transcribed spacer (ITS) region was performed in $20 \mu \mathrm{L}$ PCR reactions that contained $2 \mu \mathrm{L}$ genomic DNA (at $\sim 20 \mathrm{ng} / \mu \mathrm{L}$ ) from the fungal isolate, $10 \mu \mathrm{L}$ EmeraldAmp GT PCR Master mix $2 \times$ (Takara, Madison, WI, USA), and $0.5 \mu \mathrm{L}$ of each primer $(10 \mu \mathrm{M})$, in a thermal cycler (MyCycler; Bio-Rad Laboratories, Hercules, CA, USA). MED1/MED2 primers were used, which are specific for B. mediterranea [32]. The PCR products ( $9 \mu \mathrm{L}$ per sample) were separated by electrophoresis in $1.5 \%$ agarose gels stained with Red Gel (Biotium, Hayward, CA, USA), then visualized and captured using an imagining system (Gel Doc XR; BioRad, Hercules, CA, USA). The same ITS region was also amplified from fungal isolates with universal primers ITS1/ITS4 [33]. Amplicons from three isolates (WP101, WP20, WP376), were purified using Wizard SV gels and PCR clean-up kits (Promega Corporation, Madison, WI, USA), and quantified using the biophotometer (Eppendorf, Hamburg, Germany). Sequencing was carried out by Genewiz UK. The Bioedit software, v. 7.0.0 (http://www.mbio.ncsu.edu/Bioedit/bioedit.html, accessed on 12 April 2021) was used to cut off $20 \mathrm{bp}$ to $30 \mathrm{bp}$ of the terminal end sequence. All of the sequences were used as the query sequences in BLAST searches (http://blast.ncbi.nlm.nih.gov/Blast.cgi, accessed on 26 April 2021), to determine the nucleotide identities available in GeneBank NCBI. The nucleotide sequences were deposited in the NCBI database (MZ407593-MZ407595).

\subsection{Deadwood and Associated Lignicolous Macrofungi}

As deadwood and deadwood-dwelling macrofungi are fundamental for the maintenance of the biodiversity of forest ecosystems, the quantity and quality of the deadwood served as a proxy indicator for the level of biodiversity of Castelfidardo Forest. In particular, the deadwood was classified into standing dead trees (snags) and lying dead woody debris (logs). The quantities were expressed as percentages, considering the snags and logs with respect to the total number of oak trees in each plot.

The associated lignicolous macrofungal assemblage was analyzed concurrently. The macrofungi were collected gently and taken to the laboratory for detailed mycological examination.

\subsection{Climatic Data}

Data for the minimum, maximum, and average temperatures, and for the average annual and seasonal rainfall for the period 1951-2015 were obtained from the Regional Informative System located at Ancona Torrette 2944 (RT 701) $\left(13^{\circ} 26^{\prime}, 43^{\circ} 36^{\prime}\right)$.

\section{Results}

\subsection{Phytosanitary Monitoring}

A total of 471 oak trees were assessed from May to July 2015 for their health conditions in the five plots (Table 1). Many of the trees showed an advanced decline. The patterns of symptom appearance showed a succession of symptoms of increasing severity. Oaks in the initial stages of decline showed some nonspecific symptoms, such as leaf yellowing, early leaf browning, and thinning of canopy cover. Those in advanced states of decline showed foliar rolling and leaf wilting, production of epicormic shoots on the main branches and stems, and loss of branches, which eventually lead to tree mortality.

The emission of dark-brownish mucilaginous exudates through the bark (Figure 2A,B) occurred mainly during the growing season, and this was recorded for $7.2 \%(34 / 471)$ of the trees. Debarking the trees at the points of emission of exudates showed clearly visible necrotic areas of the underbark tissue. Furthermore, the trees with these symptoms often showed marked transparency of the canopy. Trees with production of exudates through the bark were more frequently recorded for plots \#5 and \#2, at 9.7\% (11/114 trees) and $8.2 \%(4 / 49)$, respectively (Figure 3A). Epicormic shoot formation along the main trunk was recorded for $42.7 \%(201 / 471)$ of the trees (Figure 2C,D), and it occurred equally in all 
of the five plots (Figure 3B). Charcoal cankers erupted through the bark in about $27.6 \%$ $(130 / 471)$ of the trees (Figure 2E). In cross-sections of the trunks, necrosis of the xylem and wood decay were observed in correspondence with the black carbonaceous stromata that had developed externally (Figure 2F). The charcoal-black cankers were more frequently recorded for plot \#3, at 40.0\% (38/95), followed by plots \#4 and \#5, at 30.3\% (49/162) and $25.4 \%(29 / 114)$, respectively; in plots \#1 and \#2, occurrence of the typical charcoalblack surface was lower (Figure 3 C). Declining trees generally died in the growing season following the appearance of these erumpent, coriaceous black stromata. In plot \#4, there were sporadic fallen trees that showed root rot and thick, black, string-like structures, which were usually seen under the bark or in the soil near the roots, as typical structures of Armillaria sp. (Figure 2G,H).

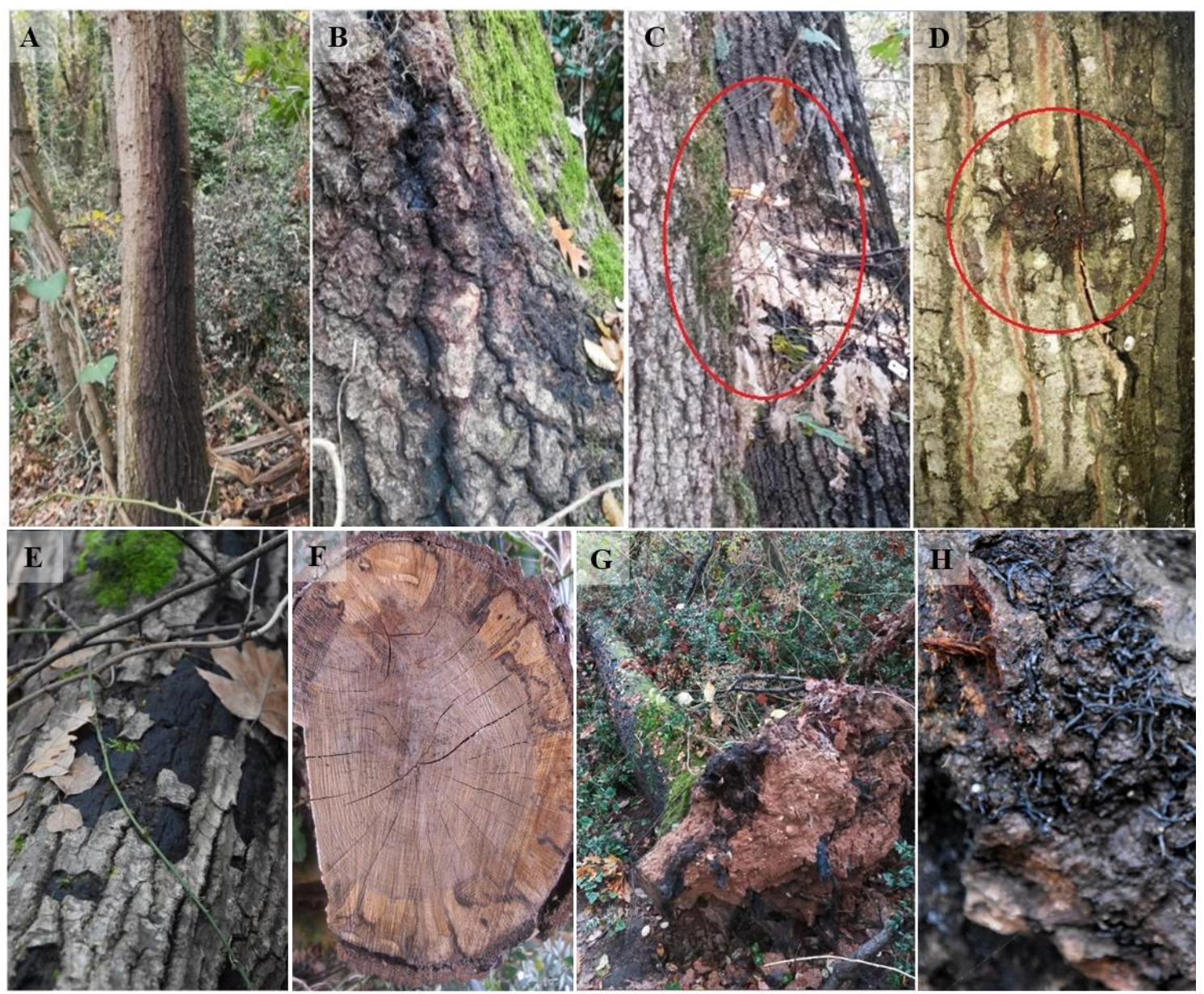

Figure 2. Representative photographs of main symptoms observed on the stems of declining oak trees in Castelfidardo Forest (Castelfidardo, AN, Italy). (A,B) Dark-brownish exudates. (C,D) Epicormic shoot proliferation. (E) Charcoal cankers erupting through the bark. (F) Cross-section of a tree with discoloration and decay of the outermost portions of the woody cylinder in correspondence with areas of external development of B. mediterranea carbonaceous stromata; $(\mathbf{G})$ Lying tree with clear symptoms of root rot. (H) Dark rhizomorphs of Armillaria spp. under the oak bark. 

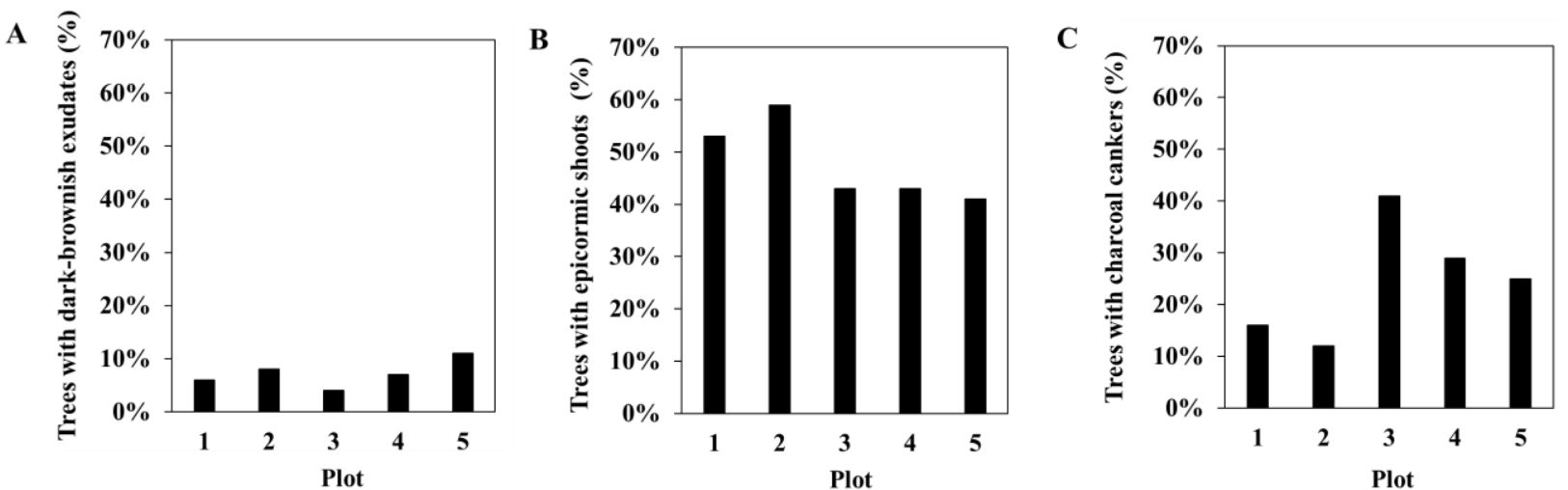

Figure 3. Quantification of the symptoms of oak decline recorded for the five experimental plots (\#1-\#5) in Castelfidardo Forest. (A) Dark-brownish exudates. (B) Epicormic shoot proliferation. (C) Charcoal cankers.

\subsection{Mycological and Molecular Identification}

We sporadically isolated from the bark tissue of oaks some fungi belonging to the genera Botryosphaeria, Diplodia, Neofusicoccum, Cytospora, Discula (Apiognomonia). However, we focused our attention on the agent of charcoal canker B. mediterranea as the incidence of this fungus was, in terms of isolation frequencies, extraordinarily higher.

Stereoscopic observations revealed carbonaceous, perithecial stromata in all of the 50 samples. The stromata appeared slightly convex, ellipsoid, and elongated, 7.2 to $20.5 \times 3.5$ to $4.2 \mathrm{~cm}$. Perithecia were ovoid to tubular, 0.74 to $0.80 \times 0.12$ to $0.15 \mathrm{~mm}$. A total of 152 fungal colonies were obtained in purity, most of which $(94.1 \% ; 143)$ were identified as B. mediterranea by mycological examination of their distinguishing micromorphological traits (Figure 4). The colonies completely filled the agar plates (diameter, $90 \mathrm{~mm}$ ) after 7 days of incubation at $25^{\circ} \mathrm{C}$. The colonies were white-grey in color and velvety (viewed from the top). Short-stipitate, amyloid asci that were dark brown were observed; these produced ellipsoid ascospores, $14 \mu \mathrm{m}$ to $19 \times 7$ to $9 \mu \mathrm{m}$, which perfectly matched the description by Mirabolfathy et al. [34].
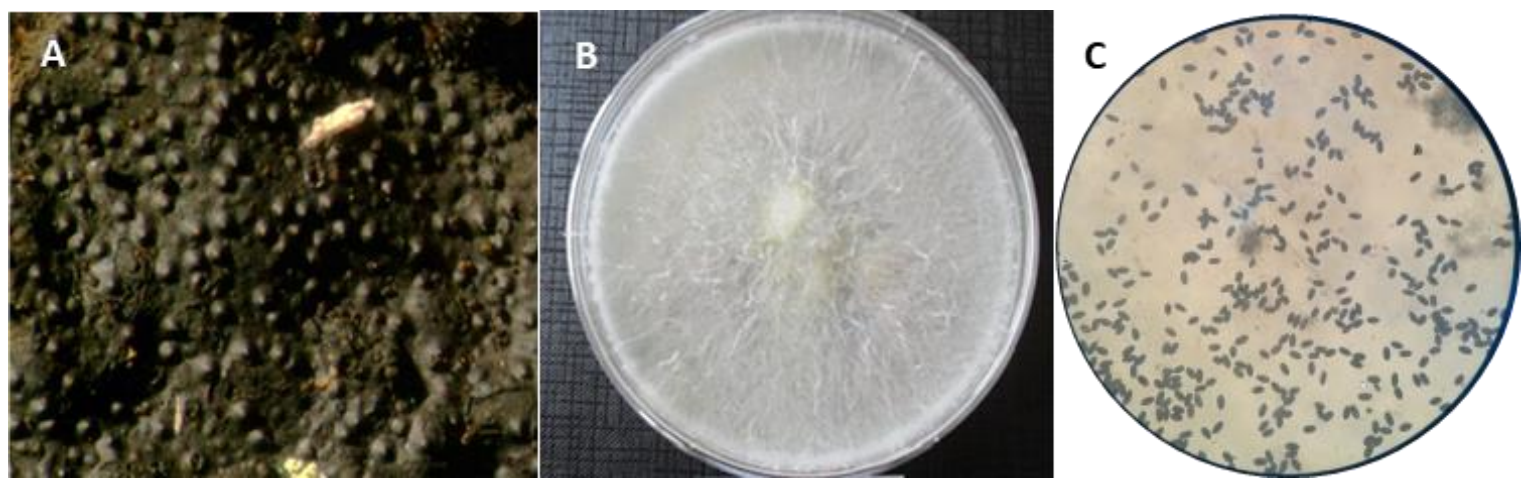

Figure 4. Representative images of carbonaceous stromata of $B$. mediterranea harboring perithecia, with a clearly visible layer of ostioles on its surface. (A) As observed under the stereo microscope. (B) A colony of B. mediterranea after 5 days on a PDA plate at $25^{\circ} \mathrm{C}$. (C) Ascospores of B. mediterranea as observed under the microscope.

No reproductive structures were observed in cultures that could be used to identify the microorganisms on a micromorphological basis. The reverse of the colonies were darker, tending to dark grey-black. Colonies of Trichoderma sp. were also sporadically isolated from the black carbonaceous stroma (four isolates).

The morphological identification of the fungi was supported by molecular identification. The DNA extraction protocol was very efficient, and provided $\sim 210 \mathrm{ng} / \mu \mathrm{L}$, with high quality (A260/280 > 1.87; A260/230 > 1.92). Only a few of the extracted samples $(n=6)$ 
showed low quality DNA values (A260/280 < 1.80; A260/230 < 1.80), and these were not processed further.

Amplification with the specific MED1/MED2 primers gave fragments of the expected length (377 bp) in all 25 of the samples analyzed. No ambiguous bands were generated, and the lack of bands in the water control test confirmed the absence of contamination. A portion of the ITS region (approximately $580 \mathrm{bp}$ ) was sequenced for additional confirmation of the identity of the fungus. Three nucleotide sequences selected revealed 100\% identity with reference sequence MT819849 in the NCBI database, as B. mediterranea isolated from Quercus suber in Portugal.

\subsection{Deadwood and Deadwood-Dwelling Mycobiota}

The ground within Castelfidardo Forest was characterized by high amounts of deadwood, for all of the plots investigated. Plot \#2 showed the lowest abundance of snags $(12.2 \%$, versus total number of oak trees) and logs $(4.0 \%)$, while the highest abundance was for plot \#5 (39.5\%, 18.4\%, respectively) (Figure 5).

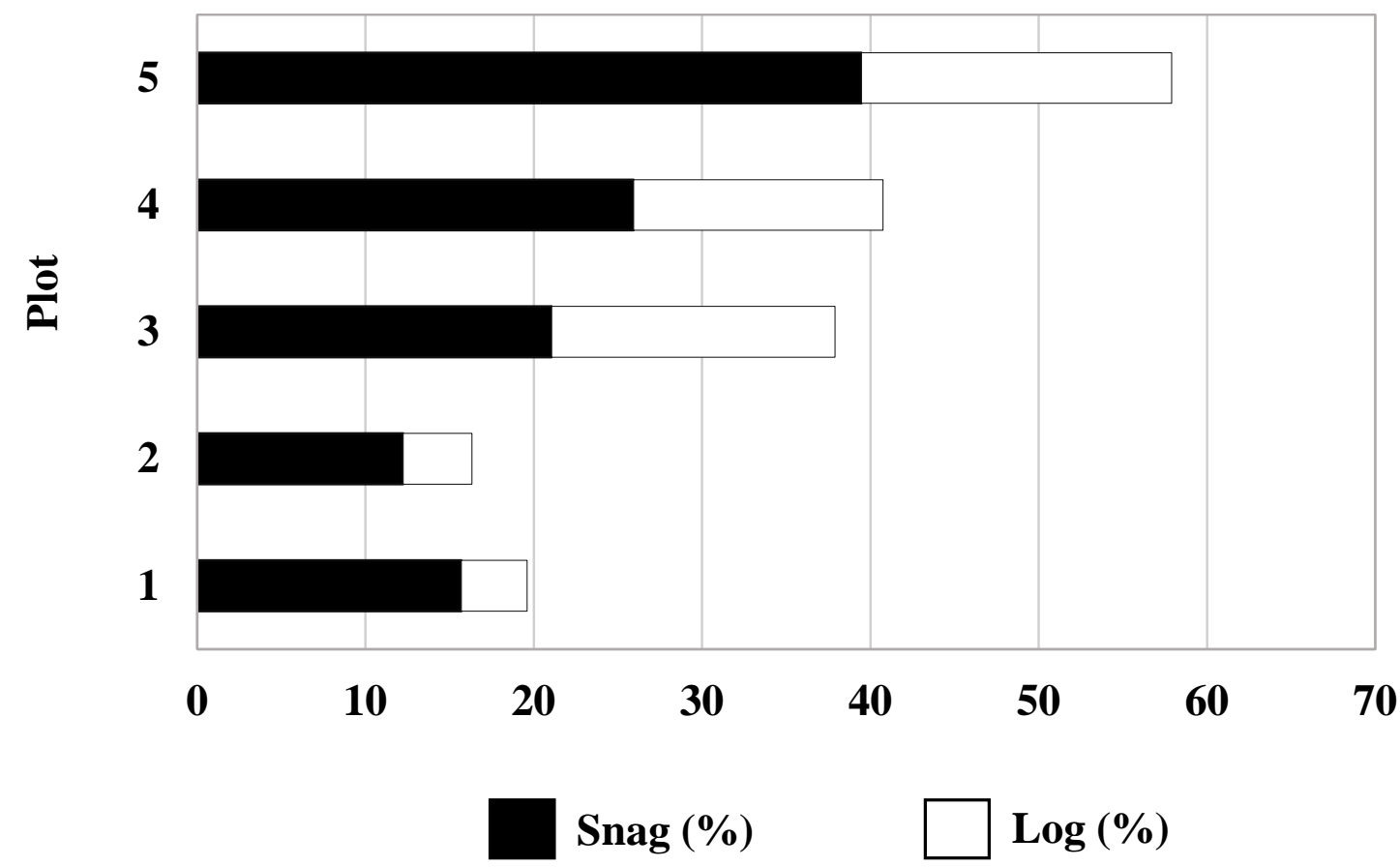

Figure 5. Abundance and type of deadwood (\% of snags and logs) recorded in the five plots in Castelfidardo Forest (Castelfidardo, AN, Italy).

The deadwood was colonized by various fungi and other saprophytic microorganisms that thrive on dead and/or decaying trees. Most of these fungi belonged to Basidiomycetes. The most frequently found in plots \#4 and \#5 were Armillaria mellea, Macrolepiota spp., Trametes spp., and Artomyces spp., while in plots \#1, \#2, and \#3 they were mainly Pluteus spp., Hypholoma spp., Macrolepiota spp., Armillaria mellea and Armillaria ostoyae (Figure 6). 


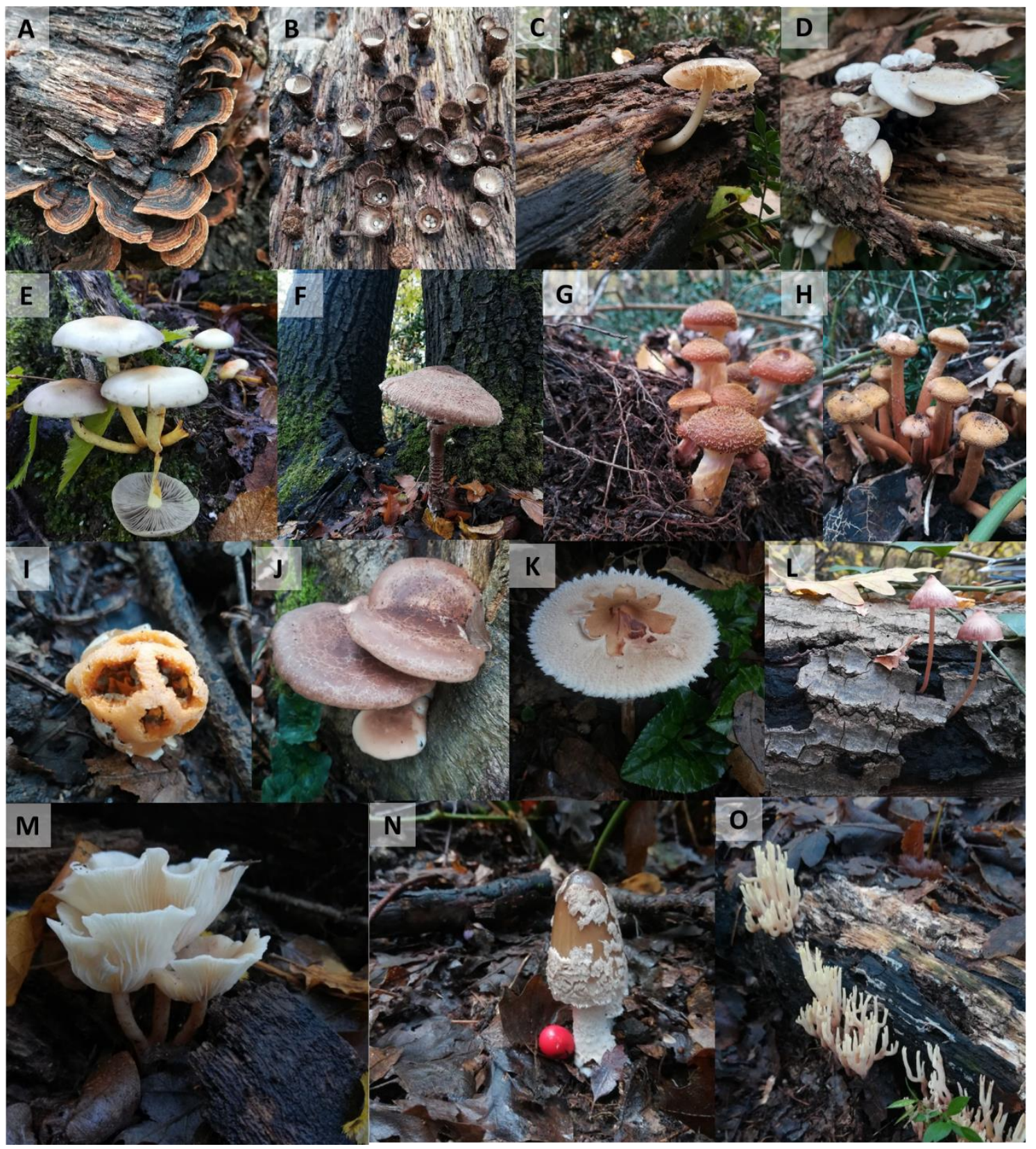

Figure 6. Representative photographs of the main macrofungi associated with the deadwood in Castelfidardo Forest (Castelfidardo, AN, Italy): (A) Trametes spp. (B) Cyathus spp. (C) Pluteus spp. (D) Postia spp. (E) Hypholoma spp. (F) Macrolepiota spp. (G) Armillaria ostoyae. (H) Armillaria mellea. (I) Clathrus spp. (J) Tapinella spp. (K) Macrolepiota spp. (L) Mycena spp. (M) Micromphale spp. (N) Coprinus spp. (O) Artomyces spp.

\subsection{Climatic Data}

Analysis of climatic data related to Castelfidardo Forest revealed that the average annual temperature $\left(17^{\circ} \mathrm{C}\right)$ recorded over the period from 2001 to 2015 has increased by $2{ }^{\circ} \mathrm{C}$ with respect to the historical series (1957-2000) (Figure 7). For rainfall, there were no evident differences, with two negative peaks recorded in $1983(376 \mathrm{~mm})$ and 2014 $(488 \mathrm{~mm})$. A more detailed analysis of the climatic data relating to the growing seasons from 2001 to 2015 revealed that in the spring and summer periods for that time interval, the temperatures increased by $2{ }^{\circ} \mathrm{C}$ and $2.5^{\circ} \mathrm{C}$ respectively, compared to the former period of 1957 to 2000. 


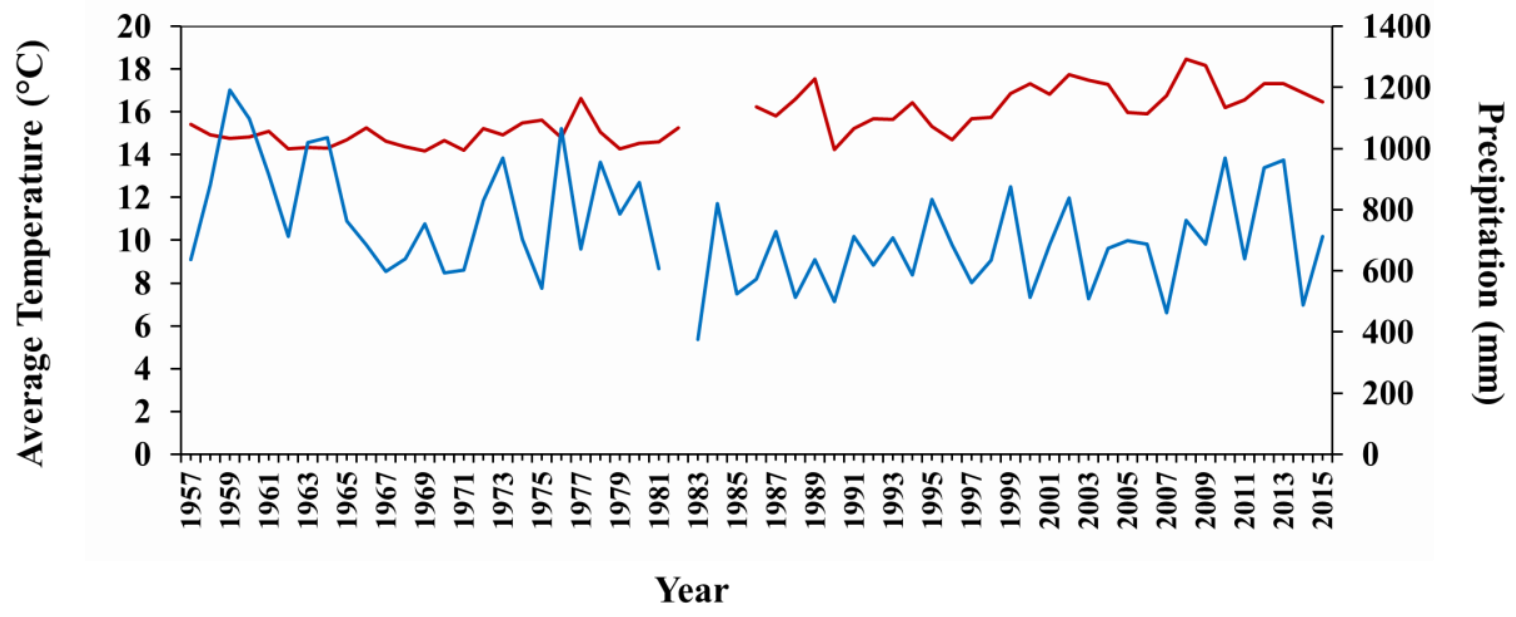

Figure 7. Graph of mean annual temperature (red lines) and rainfall (blue lines) cycles recorded from 1957 to 2015 at the Ancona Torrette 2944 weather station (RT 701) $\left(13^{\circ} 26^{\prime}, 43^{\circ} 36^{\prime}\right)$ (Regional Informative System).

\section{Discussion}

Oak forest ecosystems are of paramount importance in the Mediterranean basin due to the multiplicity of functions and services they provide in this region. Indeed, this region is at risk of desertification due to climatic and socio-economic driving forces, including rainfall variability, droughts, changes in land-use patterns, overgrazing, and demographic saturation of rural areas [35]. Oak formations have crucial roles here for the prevention of land degradation and for climate mitigation, carbon storage, and the safeguarding of the environment; they also generate economic, esthetic and landscaping benefits [25].

Unfortunately, Mediterranean oak forests have been plagued by oak decline for decades now, which is a phenomenon that appears strongly related to climate anomalies, as mainly heat stress, but also water scarcity and droughts $[18,36]$. Indeed, the Mediterranean region is a hotspot for climate change, as it is characterized by a negative water balance and pronounced warming $[37,38]$. This region is currently experiencing high water stress conditions and prolonged droughts, and these are worsening the effects of climate change, with a strongly negative impact on plant biomass production. Our analysis of climatic data showed increased temperatures during spring and summer for the period from 2001 to 2015 in the Castelfidardo area, which confirms the general warming trend that is constraining the whole Mediterranean region.

The stressful conditions determined by the water deficit, high temperatures, and droughts have created conditions conducive to the pervasive spread of the thermophilic fungus $B$. mediterranea in oak forests [39]. Several fungal species have also been isolated from trunk and branch cankers as well as from twigs and foliage of declining oaks, including Botryosphaeria dothidea, Diplodia corticola, Diplodia seriata, Neofusicoccum paroum, Cytospora spp., Discula quercina, and Neocucurbitaria cava [22,23,40,41]. The occurrence of these fungi was relatively erratic in the plots investigated, with lower isolation frequency compared to B. mediterranea. However, in particular here, we focused our attention on trees with evident symptoms of decline that were accompanied by the specific presence of $B$. mediterranea stromata. The relationship between oak decline, climate change, and the proliferation of B. mediterranea has been well documented in Mediterranean countries [12,42-46]. Indeed, recent outbreaks of $B$. mediterranea in countries where it had not been reported to cause harm, like in Turkey, Iran, Slovenia [47,48], and Croatia [49], confirm that this fungus is expanding its range and is accentuating its role as a contributing factor to the decline of oak formations.

Members of the Xylariaceae fungi are widely known for surviving across a range of lifestyles. They live as saprotrophs, as they can decompose many natural substrates, and they can also be pathogenic, promoting disease on living hosts, and especially those that are water-stressed. The Xylariaceae fungi can persist within trees in a latent stage, due 
to their endophytic aptitude [50]. B. mediterranea is a weakness pathogen that can live as an endophyte inside healthy plant tissues, thus causing extensive, although symptomless, infections. Such a cryptic existence can last for undefined periods, as long as the host does not become weakened by adverse environmental conditions. When stressful conditions that alter the carbohydrate physiology in trees occur, B. mediterranea switches to a pathogenic behavior to extensively colonize its debilitated host. This pathogenic endophyte then moves externally to sporulate profusely over the plant surfaces, a mechanism used to escape from a dying tree and colonize other trees that are already severely weakened, and possibly injured [11,23].

The aggressive colonization of oaks by B. mediterranea in the Castelfidardo Forest must thus be mainly ascribed to the chronic debilitation of these trees by hot temperatures, recurrent water deficit and droughts. Exposure to these environmental adversities will have triggered tree infection by this opportunistic fungus whereby its pathogenic action will also be facilitated by the intrinsic, low resilience of this residual forest. As a relict population, Castelfidardo Forest is more prone to any disturbance. Indeed, the extent of oak decline in Castelfidardo Forest appears greater than for other oak stands of the Italian Peninsula. Millennia of anthropogenic pressure, which was mainly represented by agricultural encroachment and overgrazing, led to the isolation of this residual portion of primeval forest. Such forest fragmentation can result in long-lasting and complex changes in biodiversity that can go beyond the loss of species, and thus include alterations to the functional diversity of the remaining communities, with isolated forests being more fragile and vulnerable [51].

The saprophytic stage is of fundamental importance in the epidemiology of B. mediterranea in Mediterranean oak stands. Through its extensive production of stromatal charcoal cankers, this xylariaceous fungus can introduce massive amounts of spores into the oak forest ecosystem, enormously increasing its biomass. The number of individuals introduced at a given location is a primary determinant of the successful establishment of an invasive organism into new environments [52]. On the other hand, the importance of propagule pressure in the spread of fungal pathogens and in the colonization of new hosts in oak stands has already been established [53].

Recent studies have shown how some functional traits can exacerbate the negative effects of drought, such as stand density and intraspecific and interspecific competition, which can then predispose trees to decline [54,55]. The Castelfidardo Forest was subjected to intense cutting in 1970, which has not been followed by any other interventions to date. This lack of management for half a century has had repercussions on the tree physiology and vigor; in particular, the high density of the stands causes excessive competition among the trees for the already limited resources (i.e., water, nutrients, light). This has led to depletion of the plant carbon reserves, and therefore to less resistance to colonization by the weakness pathogen $B$. mediterranea. Indeed, higher incidence of charcoal canker and higher tree mortality were recorded for Q. robur in plot \#3 and for Q. cerris in plots \#4 and \#5. In these plots, tree densities were much higher than in plots \#1 and \#2. Differential susceptibility to decline across oak species was shown in previous studies. In particular, in France, Q. robur was more susceptible than Quercus petraea [56]. In North America, species of the red oak group were more susceptible than those of the white oak group [57]. In central and southern Italy, Q. cerris is more susceptible to decline than Q. pubescens [58].

In the present study, the disease caused by B. mediterranea was also tree-density dependent, and it represented only the terminal stage of infection. In this context, the fungus would function as an ecological factor that regulates the structure and composition of forest stands, to make them better suited to changing environmental conditions [59].

We recorded an abundance of deadwood that was equally distributed across all of the plots. The role of deadwood in forest ecosystems is linked to various aspects, which include improvement of natural diversity [60], storage and slow release of carbon and nutrients [61,62], maintenance of soil fertility, creation of pedoclimatic conditions conducive to natural regeneration of the forest, conservation of the soil, and improvement 
of the stability of slopes from hydrogeological risk [63]. The deadwood richness of the Castelfidardo Forest suggests that the carbon reserves in the stand are substantial and can therefore be used by the trees. However, it must be considered that when trees are chronically impaired by abiotic (i.e., environmental) and biotic (mainly anthropogenic) stressors beyond a threshold of tolerance, their energies become so depleted that they can no longer benefit from the availability of substrate. This happens especially to physiologically overmature and veteran trees, like the majority of oaks in Castelfidardo Forest [64,65]. Armillaria mellea and A. ostoyae were also associated with the deadwood. These two Agaricales deserve special attention because they play a central role in the dynamics of numerous woody ecosystems [66]. They are ubiquitous species, more commonly found in mature stands with an abundance of old trees, where they play a valuable ecological role in the recycling of dead wood. However, A. ostoyae and A. mellea are also polyphagous, facultative parasites with parasitic ability, causing white rot to a number of host species [67]. In Castelfidardo Forest these two fungi live preferentially as saprotrophs on dead wood and only sporadically are they found to attack pathogenically live but visibly weakened trees [65].

\section{Conclusions}

The present study focused on the decline of oaks in Castelfidardo Forest, which is a forest of great ecological importance. The attacks of B. mediterranea on oaks in this forest have increased dramatically in recent years and must be related to hot temperatures and recurrent droughts which chronically weaken trees (Eugenio Paoloni, personal communication). The life history strategy of $B$. mediterranea has been investigated in other oak woods of central Italy where it emerged, as in this study, that the agent of charcoal canker takes advantage of environmental stresses to aggressively colonize physiologically impaired oaks [68]. Since we cannot interfere with climatic conditions, to mitigate the impact of the decline, it would be advisable to reduce the source of inoculum and tree density. This opportunistic fungus sporulates abundantly on the trunks and branches of dying or standing dead trees, as well as on deadwood on the ground. Therefore, among the possible control strategies, it would be appropriate to: (i) eliminate all dead trees with sporulating cankers; (ii) carry out thinning, to reduce tree densities, particularly in plots \#3, \#4, and \#5; and (iii) explore the possibility of using antagonistic microorganisms (e.g., Trichoderma spp.) for repressing this stress-mediated disease [69].

Author Contributions: Conceptualization: S.M. (Sergio Murolo), S.M. (Salvatore Moricca) and G.R.; data curation: S.M. (Sergio Murolo); formal analysis: S.M. (Sergio Murolo), J.C.; investigation: S.M. (Sergio Murolo), A.S., F.M., L.C., F.C.; methodology: S.M. (Sergio Murolo), J.C.; project administration: S.M. (Sergio Murolo), G.R., S.M. (Salvatore Moricca); Supervision: S.M. (Sergio Murolo) and S.M. (Salvatore Moricca); writing—original draft: S.M. (Sergio Murolo), J.C., writing—review and editing: S.M. (Sergio Murolo), S.M. (Salvatore Moricca), J.C., G.R. All authors have read and agreed to the published version of the manuscript.

Funding: This work was partially supported by Marche Polytechnic University Project 2014.

Data Availability Statement: All data generated or analysed during this study are included in this published article.

Acknowledgments: We would like to thank the Fondazione Ferretti, which kindly supported our research activities, and Eugenio Paoloni who provided us with precise and timely information on the incidence of charcoal canker in Castelfidardo Forest in the years preceding this study. Claudia Perini, from the University of Siena, and Massimo Panchetti, from Mycologist Association "T. Cicconofri" (Falconara Marittima, AN, Italy) are also acknowldged for their invaluable support in identifying the macrofungi associated with deadwood.

Conflicts of Interest: The authors declare that they have no conflict of interest. 


\section{References}

1. Manion, P.D. Tree Disease Concepts; Prentice-Hall N.J.: Englewood Cliffs, NJ, USA, 1991.

2. Hennon, P.E.; D'Amore, D.; Wittwer, D.; Johnson, A.; Schaberg, P.; Hawley, G.; Beier, C.; Sink, S.; Juday, G. Climate warming, reduced snow, and freezing injury could explain the demise of yellow-cedar in southeast Alaska, USA. World Resour. Rev. 2006, $18,427-450$.

3. Worrall, J.J.; Rehfeldt, G.E.; Hamann, A.; Hogg, E.H.; Marchetti, S.B.; Michaelian, M.; Gray, L.K. Recent declines of Populus tremuloides in North America linked to climate. For. Ecol. Manag. 2013, 299, 35-51. [CrossRef]

4. Bendixsen, D.P.; Hallgren, S.W.; Frazier, A.E. Stress factors associated with forest decline in xeric oak forests of south-central United States. For. Ecol. Manag. 2015, 347, 40-48. [CrossRef]

5. Gaylord, M.L.; Kolb, T.E.; McDowell, N.G. Mechanisms of piñon pine mortality after severe drought: A retrospective study of mature trees. Tree Physiol. 2015, 35, 806-816. [CrossRef] [PubMed]

6. Ragazzi, A.; Vagniluca, S.; Moricca, S. European expansion of oak decline: Involved microorganisms and methodological approaches. Phytopathol. Mediterr. 1995, 34, 207-226.

7. Henriques, J.; Inacho, M.L.; Lima, A.; Sousa, E. New outbreaks of charcoal canker on young cork oak trees in Portugal. IOBC-WPRS Bull. 2012, 76, 85-88.

8. Conte, A.L.; Di Pietro, R.; Iamonico, D.; Di Marzio, P.; Cillis, G.; Lucia, D.; Fortini, P. Oak decline in the Mediterranean basin: A study case from the southern Apennines (Italy). Plant Sociol. 2019, 56, 69-80.

9. Ciesla, W.M.; Donaubauer, E. Decline and Dieback of Trees and Forests: A Global Overview (No. 120); Food and Agriculture Org.: Rome, Italy, 1994.

10. Führer, E. Oak decline in central Europe: A synopsis of hypotheses. In Proceedings: Population Dynamics, Impacts, and Integrated Management of Forest Defoliating Insects; General Technical Report NE-247; Kulhavy, D., Ross, W.G., Cahal, R.R., Eds.; USDA For. Serv: Radnor, PA, USA, 1998; pp. 7-24.

11. Moricca, S.; Ragazzi, A. Fungal endophytes in Mediterranean oak forests: A lesson from Discula quercina. Phytopathology 2008, 98 , 380-386. [CrossRef] [PubMed]

12. Vannini, A.; Lucero, G.; Anselmi, N.; Vettraino, A. Response of endophytic Biscogniauxia mediterranea to variation in leaf water potential of Quercus cerris. For. Pathol. 2009, 39, 8-14. [CrossRef]

13. Ghanbary, E.; Fathizadeh, O.; Pazhouhan, I.; Zarafshar, M.; Tabari, M.; Jafarnia, S.; Parad, G.A.; Bader, M.K.-F. Drought and pathogen effects on survival, leaf physiology, oxidative damage, and defense in two Middle Eastern oak species. Forests 2021, 12, 247. [CrossRef]

14. Keča, N.; Koufakis, I.; Dietershagen, J.; Nowakowska, J.A.; Oszako, T. European oak decline phenomenon in relation to climatic changes. Folia For. Polon. Ser. A For. 2016, 58, 170-177. [CrossRef]

15. Panzavolta, T.; Panichi, A.; Bracalini, M.; Croci, F.; Benigno, A.; Ragazzi, A.; Tiberi, R.; Moricca, S. Tree pathogens and their insect-mediated transport: Implications for oak tree die-off in a natural park area. Glob. Ecol. Conserv. 2018, 15, e00437. [CrossRef]

16. Breshears, D.D.; Cobb, N.S.; Rich, P.M.; Price, K.P.; Allen, C.D.; Balice, R.G.; Romme, W.H.; Kastens, J.H.; Floyd, M.L.; Belnap, J.; et al. Regional vegetation die-off in response to global-change-type drought. Proc. Natl. Acad. Sci. USA 2005, 102, 15144-15148. [CrossRef]

17. van Mantgem, P.J.; Stephenson, N.L.; Byrne, J.C.; Daniels, L.D.; Franklin, J.F.; Fulé, P.Z.; Harmon, M.E.; Larson, A.J.; Smith, J.M.; Taylor, A.H.; et al. Widespread increase of tree mortality rates in the western United States. Science 2009, 323, 521-524. [CrossRef] [PubMed]

18. Allen, C.D.; Macalady, A.K.; Chenchouni, H.; Bachelet, D.; McDowell, N.; Vennetier, M.; Kitzberger, T.; Rigling, A.; Breshears, D.D.; Hogg, E.T.; et al. A global overview of drought and heat-induced tree mortality reveals emerging climate change risks for forests. For. Ecol. Manag. 2010, 259, 660-684. [CrossRef]

19. Millar, C.I.; Stephenson, N.L. Temperate forest health in an era of emerging megadisturbance. Science 2015, 349, 823-826. [CrossRef] [PubMed]

20. Mariotti, A.; Pan, Y.; Zeng, N.; Alessandri, A. Long-term climate change in the Mediterranean region in the midst of decadal variability. Clim. Dyn. 2015, 44, 1437-1456. [CrossRef]

21. Polade, S.D.; Gershunov, A.; Cayan, D.R.; Dettinger, M.D.; Pierce, D.W. Precipitation in a warming world: Assessing projected hydro-climate changes in California and other Mediterranean climate regions. Sci. Rep. 2017, 7, 1-10. [CrossRef] [PubMed]

22. Linaldeddu, B.T.; Sirca, C.; Spano, D.; Franceschini, A. Variation of endophytic cork oak-associated fungal communities in relation to plant health and water stress. For. Pathol. 2011, 41, 193-201. [CrossRef]

23. Moricca, S.; Linaldeddu, B.T.; Ginetti, B.; Scanu, B.; Franceschini, A.; Ragazzi, A. Endemic and emerging pathogens threatening cork oak trees: Management options for conserving a unique forest ecosystem. Plant Dis. 2016, 100, 2184-2193. [CrossRef]

24. Brewer, S.; Cheddadi, R.; Beaulieu, J.L.; Reille, M. The migration of deciduous Quercus throughout Europe since the last glacial period. For. Ecol. Manag. 2002, 156, 27-48. [CrossRef]

25. Bussotti, F.; Cenni, E.; Bettini, D.; Sarti, C.; Stergulc, F.; Feducci, M.; Capretti, P. Le condizioni dei boschi in Italia. Risultati dalle indagini estensive di Livello I (1997-2010). For. J. Silvic. For. Ecol. 2014, 11, 8-12.

26. Taffetani, F. Boschi residui in Italia tra paesaggio rurale e conservazione. In Proceedings of the Atti del Terzo Congresso Nazionale di Selvicoltura per il Miglioramento e la Conservazione dei Boschi Italiani, Sicilia, Italy, 16-19 October 2008; Ciancio, O., Ed.; Accademia di Scienze Forestali: Florence, Italy, 2009. 
27. Aleffi, M.; Allegrini, M.C.; Fuffa, X.; Muccichini, S.; Tacchi, R. Briofite e Licheni delle Selva di Castelfidardo (Marche); Università degli Studi di Camerino: Camerino, Italy, 2005.

28. Bernicchia, A.; Gorjòn, S.P. Polypores of the Mediterranean Region; Romar SRL: Verona, Italy, 2020.

29. Consiglio, G.; Papetti, C. Funghi d'Italia Vol. 1-2-3 Ed; AMB: Trento, Italy, 2009.

30. Volk, T.J.; Burdsall, H.H. A Nomenclatural Study of Armillaria and Armillariella Species (Basidiomycotina, Tricholomataceae); Fungiflora: Førde, Norway, 1995; p. 121.

31. Doyle, J.J.; Doyle, J.L. Isolation of plant DNA from fresh tissue. Focus 1990, 12, 13-15.

32. Mazzaglia, A.; Anselmi, N.; Vicario, S.; Vannini, A. Sequence analysis of the 5.8S rDNA and ITS regions in evaluating genetic relationship among some species of Hypoxylon and related genera. Mycol. Res. 2001, 105, 670-675. [CrossRef]

33. White, T.; Bruns, T.; Lee, S.; Taylor, J. Amplification and direct sequencing of fungal ribosomal RNA genes for phylogenetics. In PCR Protocols: A Guide to Methods and Applications; Innis, M.A.G.D.H., Sninsky, J.J., White, T.J., Eds.; Academic Press, Inc.: New York, NY, USA, 1990; pp. 315-322.

34. Mirabolfathy, M.; Groenewald, J.Z.; Crous, P.W. The occurrence of charcoal disease caused by Biscogniauxia mediterranea on chestnut-leaved oak (Quercus castaneifolia) in the Golestan Forests of Iran. Plant Dis. 2011, 95, 876. [CrossRef]

35. Puigdefábregas, J.; Mendizabal, T. Perspectives on desertification: Western Mediterranean. J. Arid Environ. 1998, 39, $209-224$. [CrossRef]

36. Desprez-Loustau, M.-L.; Marcais, B.; Nageleisen, L.-M.; Piou, D.; Vannini, A. Interactive effects of drought and pathogens in forest trees. Ann. Forensic Sci. 2006, 63, 597-612. [CrossRef]

37. Diffenbaugh, N.S.; Pal, J.S.; Giorgi, F.; Gao, X. Heat stress intensification in the Mediterranean climate change hotspot. Geophys. Res. Lett. 2007, 34, 1-6. [CrossRef]

38. Leite, C.; Oliveira, V.; Miranda, I.; Pereira, E. Cork oak and climate change: Disentangling drought effects on cork chemical composition. Sci. Rep. 2020, 10, 1-8.

39. Henriques, J.; Nóbrega, F.; Sousa, E.; Lima, A. Morphological and genetic diversity of Biscogniauxia mediterranea associated to Quercus suber in the Mediterranean Basin. Rev. Ciências Agrárias 2015, 38, 166-175.

40. Linaldeddu, B.T.; Maddau, L.; Franceschini, A. First report of Diplodia corticola causing canker and dieback of Quercus ilex, $Q$. petraea, and Q. suber in Corsica (France). Plant Dis. 2017, 101, 256. [CrossRef]

41. Anselmi, N.; Cellerino, G.P.; Franceschini, A.; Granata, G.; Luisi, N.; Marras, F.; Mazzaglia, A.; Mutto Accordi, S.; Ragazzi, A. Geographic distribution of fungal endophytes of Quercus sp. in Italy. In Endophytism in Forest Trees; Ragazzi, A., Moricca, S., Dellavalle, I., Eds.; Accademia Italiana di Scienze Forestali: Firenze, Italy, 2004; pp. 73-89.

42. Vannini, A.; Valentini, R.; Luisi, N. Impact of drought and Hypoxylon mediterraneum on oak decline in the Mediterranean region. Ann. Sci. For. 1996, 53, 753-760. [CrossRef]

43. Collado, J.; Platas, G.; Pelaez, F. Identification of an endophytic Nodulisporium sp. from Quercus ilex in central Spain as the anamorph of Biscogniauxia mediterranea by rDNA sequence analysis and effect of different ecological factors on distribution of the fungus. Mycologia 2001, 93, 875-886. [CrossRef]

44. Moricca, S.; Capretti, P.; Dellavalle, I.; Ragazzi, A.; Turco, E. Differences in composition of endophytic mycobiota in twigs and leaves of healthy and declining Quercus species in Italy. For. Pathol. 2012, 33, 31-38.

45. Sánchez-Salguero, R.; Colangelo, M.; Matías, L.; Ripullone, F.; Camarero, J.J. Shifts in growth responses to climate and exceeded drought-vulnerability thresholds characterize dieback in two Mediterranean deciduous oaks. Forests 2020, 11, 714. [CrossRef]

46. Yangui, I.; Jamaâ, M.L.B.; Boutiti, M.Z.; Vettraino, A.M.; Vannini, A.; Messaoud, C. Occurrence of Biscogniauxia mediterranea in cork oak stands in Tunisia. Phytoparasitica 2021, 49, 131-141. [CrossRef]

47. Jurc, D.; Ogris, N. First report outbreak of charcoal disease caused by Biscognauxia mediterranea on Turkey oak in Slovenia. Plant Pathol. 2006, 55, 299.

48. Alidadi, A.; Kowsari, M.; Javan-Nikkhah, M.; Salehi Jouzani, G.R.; Ebrahimi Rastaghi, M. New pathogenic and endophytic fungal species associated with Persian oak in Iran. Eur. J. Plant Pathol. 2019, 155, 1017-1032. [CrossRef]

49. Diminić, D.; Kranjec Orlović, J.; Lukić, I.; Ježić, M.; Ćurković Perica, M.; Pernek, M. First report of charcoaldisease of oak (Biscogniauxia mediterranea) on Quercus spp. in Croatia. Plant Dis. 2019, 103, 1-4. [CrossRef]

50. Whalley, A.J.S. The xylariaceaous way of life. Mycol. Res. 1996, 100, 897-922. [CrossRef]

51. Zambrano, J.; Cordeiro, N.J.; Garzon-Lopez, C.; Yeager, L.; Fortunel, C.; Ndangalasi, H.J.; Beckman, N.G. Investigating the direct and indirect effects of forest fragmentation on plant functional diversity. PLoS ONE 2020, 15, e0235210. [CrossRef] [PubMed]

52. Lockwood, J.L.; Cassey, P.; Blackburn, T.M. The more you introduce the more you get: The role of colonization pressure and propagule pressure in invasion ecology. Divers. Distrib. 2009, 15, 904-910. [CrossRef]

53. Panzavolta, T.; Panichi, A.; Bracalini, M.; Croci, F.; Ginetti, B.; Ragazzi, A.; Tiberi, R.; Moricca, S. Dispersal and propagule pressure of Botryosphaeriaceae species in a declining oak stand is affected by insect vectors. Forests 2017, 8, 228. [CrossRef]

54. Greenwood, S.; Ruiz-Benito, P.; Martínez-Vilalta, J.; Lloret, F.; Kitzberger, T.; Allen, C.D.; Fensham, R.; Laughlin, D.C.; Kattge, J.; Bönisch, G.; et al. Tree mortality across biomes is promoted by drought intensity, lower wood density and higher specific leaf area. Ecol. Lett. 2017, 20, 539-553. [CrossRef] [PubMed]

55. Martínez-Vilalta, J.; Lloret, F.; Breshears, D. Drought-induced forest decline: Causes, scope and implications. Biol. Lett. 2012, 8, 689-691. [CrossRef] [PubMed] 
56. Landmann, G.; Becker, M.; Delatour, C.; Dreyer, E.; Dupouey, J.L. Oak dieback in France: Historical and recent records, possible causes, current investigations. Zustand Gefährdung Laubwäder 1993, 5, 97-114.

57. Oak, S.W.; Starkey, D.A.; Dabney, J.M. Oak decline alters habitat in southern upland forest. In Proceedings of the Annual Conference of the Southeast Association of the Fish and Wildlife Agencies, Hilton Head, SC, USA, 7-10 November 1988; Volume 42, pp. 491-501.

58. Vannini, A.; Valentini, R. Influence of water relations in Quercus cerris-Hypoxylon mediterraneum interaction: A model of drought induced susceptibility to a weakness parasite. Tree Physiol. 1994, 14, 129-139. [CrossRef]

59. Vannini, A.; Scarascia Mugnozza, G. Water stress: A predisposing factor in the pathogenesis of Hypoxylon mediterraneum on Quercus cerris. Eur. J. For. Path. 1991, 21, 193-202. [CrossRef]

60. Nordén, B.; Ryberg, M.; Götmark, F.; Olausson, B. Relative importance of coarse and fine woody debris for the diversity of wood-inhabiting fungi in temperate broadleaf forests. Biol. Conserv. 2004, 117, 1-10. [CrossRef]

61. Holub, S.M.; Spears, J.D.H.; Lajtha, K. A reanalysis of nutrient dynamics in coniferous coarse woody debris. Can. J. For. Res. 2001, 31, 1894-1902. [CrossRef]

62. Laiho, R.; Prescott, C.E. The contribution of coarse woody debris to carbon, nitrogen, and phosphorus cycles in three Rocky Mountain coniferous forests. Can. J. For. Res. 1999, 29, 1592-1603. [CrossRef]

63. Hagan, J.M.; Grove, S.L. Coarse woody debris. J. For. 1999, 97, 6-11.

64. Allen, C.D.; Breshears, D.D.; McDowell, N.G. On underestimation of global vulnerability to tree mortality and forest die-off from hotter drought in the Anthropocene. Ecosphere 2015, 6, 129. [CrossRef]

65. Holuša, J.; Lubojacký, J.; Čurn, V.; Tonka, T.; Lukášová, K.; Horák, J. Combined effects of drought stress and Armillaria infection on tree mortality in Norway spruce plantations. For. Ecol. Manag. 2018, 427, 434-445. [CrossRef]

66. Shaw, C.G., III; Kile, G.A. (Eds.) Armillaria Root Disease; Agricultural Handbook No. 691; Forest Service, US Department of Agriculture: Washington, DC, USA, 1991.

67. Heinzelmann, R.; Dutech, C.; Tsykun, T.; Labbé, F.; Soularue, J.P.; Prospero, S. Latest advances and future perspectives in Armillaria research. Can. J. Plant Path. 2019, 41, 1-23. [CrossRef]

68. Moricca, S.; Bracalini, M.; Croci, F.; Corsinovi, S.; Tiberi, R.; Ragazzi, A.; Panzavolta, T. Biotic Factors Affecting Ecosystem Services in Urban and Peri-Urban Forests in Italy: The Role of Introduced and Impending Pathogens and Pests. Forests 2018, 9, 65. [CrossRef]

69. Costa, D.; Tavares, R.M.; Baptista, P.; Lino-Neto, T. Cork Oak endophytic fungi as potential biocontrol agents against Biscogniauxia mediterranea and Diplodia corticola. J. Fungi 2020, 6, 287. [CrossRef] [PubMed] 